\title{
Interrelated and Multi-Dimensional Factors Affecting Quality Basic Education in Nandom Municipality of the Upper West Region of Ghana
}

\author{
Lazarus Derkong-Dery \\ (Corresponding Author) \\ Ghana Education Service, Box 15, Wa, UWR \\ lazarusder@yahoo.com \\ and \\ Gideon Kofi Agbley \\ Department of Sociology and Social Works, \\ SDD-UBIDS \\ dr.gagbley@uds.edu.
}

DOI//http://dx.doi.org/10.4314/gjds.v18i1.2

\section{ABSTRACT}

Worldwide, quality education is a platform for social and personal development. In recent times, pupils in basic schools in Nandom Municipality seem not to acquire critical learning skills and consequently are underperforming. This paper investigates the interrelated and multi-dimensional factors affecting quality education in basic schools in the Nandom Municipality. Through the system and human capital theories, the paper draws a link between the various kinds of educational inputs pupils receive, the processing of such inputs and their outcomes, which reflect in their academic performance at the Basic Education Certificate Examination (BECE). The study employed a mixed research methods design. Cluster sampling technique and purposive sampling technique were used to select respondents. The study found that many pupils are not acquiring foundational knowledge in Literacy and Mathematics as reflected in the BECE performance due to inadequate educational resources, poor school management and supervision, and family socio-economic background factors. The study concludes that the quest for quality education for pupils would continue to be illusive unless the fundamentals underpinning quality education such as school resources and management are improved. It is recommended that government provides 
adequate educational resources for schools and reinforces the decentralisation concept of school management.

Keywords: Quality Education, Resources, Management, Pupils, Learning Achievements

\section{INTRODUCTION}

Quality education is the most powerful tool for developing efficient human resource and prosperous society in every country. Quality education creates a wellbalanced and well-informed societies and individuals with the relevant knowledge, skills, attitudes and values that enable them to live healthy lives and contribute effectively to national development (Madani, 2019; UNICEF, 2015). Quality education creates a solid platform for democracy, promotes national identity, builds healthy nations and individuals, and serves as a foundation for sustainable development across the globe (Suriyankietkaew \& Hallinger, 2019; Haseena\& Mohammed, 2015).

Over the last three decades, the concepts of equality in educational access, retention and in recent times, quality education have become a common mantra and often invoked among policy makers and activists in the global south. This is due to the disparity in academic performance between rural and urban schools as a result of disproportionate access to educational resources. However, defining the concept "quality" in education is not without its challenges due to its evasiveness, subjectivity and complexity (Haseena\& Mohammed, 2015). The term "quality" is defined as something good, excellence, standard, outstanding, satisfactory, effective, efficient, worthwhile and sound. Quality education is about how well students are learning in schools (Schindler et al., 2015).Babalola (2004) defined quality education as the worth of education in terms of the inputs, teaching and learning processes and the outcomes.

In this context, quality education refers to an effective educational system that is environmentally and pedagogically sound to provide learning opportunities for students to develop their capabilities by acquiring critical learning skills, particularly in literacy and numeracy, societal values and essential life skills that they need to become productive citizens in society. Quality education refers to the acquisition of critical knowledge, skills, values and performance of students according to national standard.

Our proxy for measuring quality education involves some factors: school infrastructure and management efficiency, family background factors and 
academic performance at the BECE. The study did not set out to measure learning outcomes as a core indicator of excellence in education, even though it is one of the variables of the concept "quality".The use of a terminal examination as a measure of quality education has been extensively debated in the past'. But the study draws attention to the fact that over the past seven years, the BECE gives equal weights to classroom work and the final examination which is written at the end of a three-year study. Therefore, the score in BECE is a reflection of the student's performance over the three years of study, comprising 50\% classroom assessment (hitherto $25 \%$ ) and $50 \%$ in the final written examination (hitherto $75 \%$ ). The BECE as the name implies, focuses on foundational knowledge needed for immediate self-employment, preparation for further training in apprenticeship or to secondary school. The acquisition of the certificate has direct implication for pupil's human capital.

The provision of quality education for all has attracted the world's attention and has been recognised as a fundamental human right. The Aichi Nagoya Declaration on Education for Sustainable Development (ESD) indicated that the provision of quality education empowers learners to transform themselves and society they live in by developing their knowledge, skills, attitudes, competences and values required for addressing global and local contextual challenges of the present and the future (Amaah, 2019; Madani, 2019; UNESCO, 2014). Goal six of the Dakar Framework for Action and goal four of the Sustainable Development Goals (SDGs) both strongly call for greater attention to improving quality education and ensuring learning outcomes are achieved by all (UNESCO, 2012). At the world education conference in 2016, it was however, noted that poor quality education is an impediment to social and economic development. It was agreed that quality teaching and learning was very fundamental element to the expansion of access, suggesting that both quantitative (expansion of educational access) and qualitative (quality teaching and learning aspects of education should go concurrently).

UNICEF (2015) reports that although many children are in school, millions of them do not learn the basics and over 250 million of students out of 650 million in school

1 Aziz Hazlina (2018).Will scrapping exams make a better education system? Opinion piece in the Strait Times provides a nuanced analysis of the debate. www.nst.com.my/opinion/columnists/2018/12/442287/. Further, Amanda Spielman (2019) Ofsted Chief Inspector argues for holistic changes to measuring quality education at https://schoolsweek.co.uk/how-ofsted-istrying-to-tackle-the-culture-of-teaching-to-the-test/ 
either do not reach primary four or complete without knowing how to read, write or do simple calculations in mathematics. Even though Ghana has been acclaimed as a regional leader in the expansion of access to education (Ghana-SDGs, 2017), poor learning achievement remains a major setback on access. It is one thing to achieve $100 \%$ in enrolment and completion rates but another thing to achieve quality education that creates opportunities for pupils to learn and acquire critical learning skills in schools. If children attend school but learn nothing, it means they have not received quality education.

The issue of low-quality education and the question of why many pupils not acquiring the essential learning skills and perform poorly in their examinations raise a lot of concerns and has become an area of interest for policy-makers, international organisations and researchers. The problem of low-quality education has been debated among politicians and researchers in the academia. The education sector variables such as teacher motivation, absenteeism, educational materials and teacher qualification (Casely-Hayford et al., 2013; Adu-Agyem\& Osei-Poku, 2012) and non-education sector variables such as parents educational background and family socio-economic status (Thangeda,2016; Haseena \& Mohammed, 2015; Abdallah, Fuseini, Abudu \& Nuhu, 2014) and students' effort and ambition (Ampofo \& Osei-Owusu, 2015) had been researched into and were viewed to be the causes of poor academic performance. However, how educational resources, community participation and school management influence quality learning, is still problematic.

Quality in education is dwindling as many students are learning virtually nothing (Madani, 2019) while geographical disparities in education outcomes is still glaring. UNICEF-Ghana report (2013) indicated that $84 \%$ and $65 \%$ of students in primary six in Northern Ghana are not proficient in Mathematics and English language respectively. Statistics have shown that many pupils in Nandom Municipality are not acquiring the essential concepts and skills in schools, resulting inconsistent massive failure in BECE. (BECE Performance Analysis, 2017). In 2014, the failure rate was $88.3 \%$. In 2015 , the Municipality recorded $87 \%$ failure, and was nationwide ranked 179th out of 182 districts. The district's average performance was $13.9 \%$, as compared to the regional average performance of $31.7 \%$ and a national average performance of $46.9 \%$ (GES BECE Performance Analysis Report, 2015). The consistent poor performance shows that many pupils are not getting quality education and there is learning crisis in the Nandom Municipality. This is a worrying trend in the once vibrant educational enclave of northern Ghana and a threat to its human capital development. 


\section{Theoretical Basis of the Study}

The paper adopted the System Theory analytical framework and Human Capital Theory (HCT) as a guide to examine the interrelated and multi-dimensional factors affecting quality education in Nandom Municipality. These theories are more appropriate guides to employ when examining the inputs, processes and the outputs of an organisation (Zainul-Deen, 2011 \& Mathieu et al., 2009).

\section{The System Theory Analytical Framework}

The system theory was propounded by Ludwig von Bertalanffy in Austria in the 1940 s (Haque et al., 2014). The system theory states that an organisation or an enterprise does not exist in vacuum but depends on the external environment for resources for its function. Therefore, the inputs and processes are directly proportional to the outputs (Haque et al., 2014). Crucially, the provision of quality education is interconnected, and therefore requires adequate inputs, effective processes and outputs. The learner, learning environment, content, process and outcome are interconnected.

The investment of adequate resources such as infrastructure, instructional materials, qualified teachers, finances, technology, time and motivation are key determinants of quality education (Amaah, 2019; Ramatu, 2014). The framing of system theory depicts a rectangular block consisting of three interconnected units - inputs, processes and outputs. The provision of adequate inputs and sound learning processes constitute the foundation of quality outcomes. As government, parents and NGOs provide the inputs, headmasters and teachers utilise these inputs in the teaching and learning processes to make sure that the learners acquire the essential learning skills.

One of the strengths of the system theory analytical framework is that it informs stakeholders to always consider investment of resources in education as the foundation of quality education. The theory provides framework for policymakers to make policies that ensure adequate investment on managers and teachers who are in charge of the educational management and the learning processes if they want to achieve quality education. The input-process-output theory, however, fails to inform how the inputs, processes and outputs are interconnected and how one stage translates to another. Moreland (1996) rejects the claim that knowledge, attitudes and behaviours are output because they can equally function as inputs and or process. 


\section{Human Capital Theory}

The Human Capital Theory (HCT) was propounded by Adam Smith in the $18^{\text {th }}$ century and was popularised by Schultz in 1961 (Becker, 1994). The human capital theory is a framework that basically examines the relationships between investment on one side and education, economic growth and social well-being on the other. The human capital theory states that investment in education, training and health increases people's aptitudes, talent, knowledge, abilities, productivity, well-being, economic and social transformation in society. Bohlander, Snell and Sherman (2001) defined human capital as knowledge, skills and capabilities of individuals that have economic value to an organisation. Schultz (1961) explained HCT as the knowledge and skills people obtained as capital through the process of education. Olaniyan and Okemakinde (2008) explained that the HCT basically considers education as key and also as form of investment to enhance people's lives economically. The development of any society largely depends on how the people are educated and how resources are invested and managed in the education of people. The theory hypothesises that expenditure or investment on education, job training and health are capital investments that will produce economic and social returns at the individual, family, community and national levels (Becker, 1994). The expenditure or investments on education is capital investments which will let the individuals and the society derive economic benefits such as wages and increased in GDP.

Highlighting the relevance of HCT, Zainul-Deen (2011) noted that educated persons have strong linkages with other factors of production such as capital, land and entrepreneurship to increase productivity in society. Samuel (2012) concurs with Olaniyan and Okemakinde's (2008) assertion that an educated nation is a productive nation. The author maintains that the human resource base constitutes the wealth of every nation but not the natural resources. Through adequate investment in education, efficient educated workforce is produced to man the nation and improve lives in society. The HCT suggests that education and training increase productivities of employees by imparting relevant knowledge, skills, values and attitudes thereby raising workers future incomes (Becker, 1994). Investment in human capital ensures that the new generation is given the relevant knowledge, skills and values which have been accumulated by the previous generations; that the new generations are taught how to employ existing knowledge to develop new ideas, new processes, new production methods, new products and social services via creative approaches (Babalola, 2003). 
The major strength of HCT is that it aids policymakers and researchers to examine the relationship between investment and education. Olaniyan and Okemakinde (2008) noted that the human capital theory framework also informs stakeholders that the increase in investment on individuals' education or schooling goes with higher wages, GDP growth, lower crime rates and better health outcomes. The theory provides a useful lens, guides, creates awareness and prepares the minds of individuals, families, government and general public to be aware that pursuing education at any level involves costs and benefits.

However, the assumption that acquiring education automatically increases the salaries and wages of individuals is absolutely wrong. The nationalistic approach and application of the framework is also erroneous, as different communities and districts have different educational challenges, needs and approaches. The theory ignores management practices, experiences and motivation which are very central in the provision of quality education.

Having explored the extant literature on education quality, it is argued that adequate resources, effective school management and supervision, and community participation and accountability are crucial determinants for the provision of quality education. A statement by UNCESCO (2014) that resources and management are critical inputs to the provision of qualityeducation underpin this argument. Specifically resources such as classroom availability, adequate furniture, appropriate textbooks and other teaching aids are essential. These are basic inputs that ensure pupils have access to adequate instructional materials, conducive environment and equate interactions with teachers. In addition to these factors, the study probed teacher qualifications as both a management and input issue in this study.

\section{METHODOLOGY}

\section{Profile of Study Area}

The study was conducted in the Nandom Municipality of the Upper West Region of Ghana. The Nandom Municipality has a population of 44,040 , which represents $6.6 \%$ of the population in the Upper West Region (GSS, 2014). The Municipality has a youthful population. People under age 15, represent 37.3\% (GSS, 2014). The illiteracy rate in the Municipality stood at $61 \%$. The district has 41 Kindergarten, 40 public primary schools, 27 Junior High schools, four Senior High /Technical/Vocational schools and one nursing training college. 


\section{Study Design}

The study employed a mixed methods approach to examine the interrelated and multi-dimensional factors affecting quality education in basic schools in the Nandom Municipality of the Upper West Region of Ghana. A concurrent mixed methods design was employed, which enabled the collecton of both quantitative and qualitative data at the same time. A mixed methods approach is appropriate particularly, when different objectives of a study can better be examined using different methods. Quantitative and qualitative data were collected concurrently within three months for analysis.

\section{Sampling Techniques}

The study used a sample frame of 435 trained teachers. A sample size of 115 participants was used for the study, representing $26 \%$ of the total teacher population size (435). Both probability and non-probability sampling techniques were used. Specifically, cluster and purposive sampling techniques were employed. Cluster sampling technique was used to group all basic schools into five clusters: Nandom Central, Nandom West, Nandom South, Nandom North and Puffien. From each cluster, six basic schools (three KG/primary schools and three JHSs) were selected using the simple random sampling technique. However, the KG and primary schools were merged because most KG schools were under the authority of the primary headteachers. Thirty basic schools were selected across the Nandom Municipality. Cluster sampling technique was employed to give fair representation to the different education circuits. One hundred and twelve key informants comprising nine pupils, five circuit supervisors, 15 Parent Teacher Association (PTA) executives and two education officials were purposively sampled for their expertise and in-depth knowledge on the subject under investigation.

\section{Data Collection Instruments}

Questionnaires were the main instruments used to collect the quantitative data. Semi-structured interview and observation guides were also used to collect qualitative data for the study.

\section{Data Management and Analysis}

The Statistical Product for Services Solution (SPSS) version 16.0 was used to process the quantitative data. Quantitative data were analysed using percentages and frequencies. Quantitative data was presented in tables and charts. The qualitative 
data were also analysed using the narrative analytical technique. The qualitative data were coded according to emergent themes. These themes were first order codes such as input factors, and second order codes such as classroom, furniture and library books availability. Another first order code adduced was management and teacher supervision. The second order codes emerging from this were teacher availability and deployment, teacher regularity and punctuality, number of exercises and assignments given within a specified period. Responses were then grouped according to these themes and sub-themes. Re-reading of the themed responses led to the emergence of patterns, similarities and differences, which formed the basis of our analysis.

\section{FINDINGS AND DISCUSSIONS}

This section is organised into school input (resources) factors, school management and teacher factors, and family background factors affecting quality education delivery. Finally, stakeholder perspectives on strategies for improving quality education are presented.

\section{Input Factors in Basic Schools in Nandom Municipality}

The input factors examined include the number of classrooms, furniture and textbooks. The principle of input-process-output theory state that for children to get quality education, adequate educational resources must be first invested.

Table1: Extent of availability of classrooms

\begin{tabular}{|l|l|l|l|l|l|}
\hline School levels & Enrolment & Resources & Ratio & Quantities & Deficit \\
\cline { 2 - 6 } & Enrolments & $\begin{array}{l}\text { Classrooms } \\
\text { available }\end{array}$ & CPR & $\begin{array}{l}\text { Pupils with } \\
\text { classrooms }\end{array}$ & $\begin{array}{l}\text { Pupils without } \\
\text { classrooms }\end{array}$ \\
\hline Kindergarten & 1521 & $15(34.5 \%)$ & $1: 101$ & $525(34.5 \%)$ & $996(65.5 \%)$ \\
\hline Primary school & 4521 & $78(60.4 \%)$ & $1: 58$ & $2730(60.4 \%)$ & $1791(39.6 \%)$ \\
\hline JHS & 2076 & $45(75.9 \%)$ & $1: 46$ & $1575(75.9 \%)$ & $501(24.1 \%)$ \\
\hline Total & 8118 & $138(59.5 \%)$ & $1: 59$ & $4830(59.5 \%)$ & $3288(40.5 \%)$ \\
\hline
\end{tabular}

Source: Field survey, 2018 Note: CPR means classroom pupil ratio

The poor nature of schools and inadequate classrooms were major factors impeding quality education delivery in basic schools in the Nandom Municipality. From Table 1, the data indicated that $65.5 \% ; 39.6 \%$ and $24.1 \%$ of the pupils for the $\mathrm{KG}$, primary and JHSs respectively had no access to concrete built classrooms for 
learning. The study showed that the classroom-pupil-ratios (CPR) stood at 1:101; 1:58 and 1:46 for KG, primary and JHSs respectively.

The inadequate infrastructure situation compelled some pupils in some schools to share classrooms with other classes, which were more than the required standard class-size of 35-40 pupils per class. This resulted in high class-sizes and congestion, which made teaching and learning difficult in most basic schools. It was found that sixty percent of the classes observed were overcrowded as a result of very high enrolment figures. The combination of different classes of students into one classroom does not only make class control and management difficult for teachers but also it makes the teaching of students from different classes in a multi-grade class an uphill task. The alternative to multi-grade classrooms is to have teachers for all classes even if they are taught under trees. The field survey further indicated that pupils sat and learnt in nine dilapidated structures out of the total of 30 schools observed. In an interview with a headmistress on the effects of school infrastructure on quality learning, she remarked:

When we come to school, we are compelled to sit under this tree because our school does not have infrastructure. We keep on shifting round the tree as the shade rotates. Whenever it threatens to rain, we close down the school because we do not have any place to run into when it is raining. This affects learning achievements as it distracts classes and reduces the contact hours (Informant interview, February, 2018).

Pupils miss learning opportunities and consequently it adversely affects pupils' overall performance. Syllabuses are not covered and as a result pupils do not achieve the standard that the pupils at that level are expected to attain. Pupils who learn under such difficult conditions are denied the full development of their capabilities and competences as they fail to acquire the essential learning skills. Instructional time is drastically reduced when schools are to close down any time it is raining. Ramatu (2014) agreed with this finding that poor school infrastructural facilities affect quality teaching and learning in school.

It was observed that poor maintenance culture was a serious issue. In all schools visited, it was found that either their doors and windows were broken down or their roofing sheets were perforated. Others had holesin the floors or cracks in the walls. These defects affect learning opportunities and pupils' performance as teaching and learning materials are often destroyed by rain and some stolen by thieves. 
The poor learning environment impairs pupils' learning achievements in school (Ramatu, 2014; Adedeji et al., 2011).

Table 2: Furniture audit in basic schools in Nandom Municipality

\begin{tabular}{|l|l|l|l|l|l|}
\hline \multirow{2}{*}{ School Level } & \multicolumn{4}{|l|}{ Pupil-Furniture Ratio } & \\
\cline { 2 - 6 } & Enrolment & $\begin{array}{l}\text { Furniture } \\
\text { available }\end{array}$ & FPR & $\begin{array}{l}\text { Pupils with } \\
\text { furniture }\end{array}$ & Furniture deficit \\
\hline Kindergarten & 1521 & $304(20 \%)$ & $1: 5$ & $304(20 \%)$ & $1217(80 \%)$ \\
\hline Primary school & 4521 & $1517(33.5 \%)$ & $1: 3$ & $1517(33.5 \%)$ & $3004(66.4 \%)$ \\
\hline JHS & 2076 & $1557(75 \%)$ & $1: 2$ & $1557(75 \%)$ & $519(25 \%)$ \\
\hline Total & 8118 & $3378(41.6 \%)$ & $1: 2$ & $3378(41.6 \%)$ & $4740(58.4 \%)$ \\
\hline
\end{tabular}

Source: Field survey, 2018 Note: FPR means Furniture Pupil Ratio

Inadequate furniture was another crucial challenging factor confronting quality education delivery in basic schools. From Table 2, the furniture-pupil-ratio among the 30 schools sampled, stood at 1:5; 1:4 and 1:2 for KG, primary and JHSs respectively. In percentage terms, $80 \% ; 52 \%$ and $25 \%$ of school children for KG, Primary and JHSs respectively of the schools visited did not have furniture to sit in class and learn. Given the fact that all levels of basic school were confronted with furniture shortage, it was observed that the lower primary and KG levels were heavily affected. Pupils without access to furniture were compelled to sit or lie on the bare floor, or on broken pieces of boards, blocks and plywood during instructional time. It was found that from the upper primary to JHS dual desks meant for two pupils each, had three or four pupils compelled to sit on one dual desk. The implication of this is that it affects quality learning and performance as pupils cannot lie on the floor and write, read, and do group work properly. Poor sitting posture due to absence of furniture has long term health implications too.

Acute shortage of textbooks was another key factor affecting quality education delivery. Per the data collected, $86.4 \%, 86.7 \%, 88.2 \%$ and $87.7 \%$ of students did not have English Language, Mathematics, Integrated Science and Citizenship/ Social Studies textbooks respectively. The pupil-core textbook ratio stood at 1:7 for English Language, and 1:8 for Mathematics, Integrated Science and Citizenship/ Social Studies. Textbooks are indispensable elements and core determinant factor of providing quality education for all. Corroborating this, a headmaster-respondent in an interview said: "Many pupils cannot read, write and work simple mathematics because the textbooks are not there". 
Another disabling factor that affected quality education delivery was poor library facilities. Out of the 30 schools visited, 14 schools had few copies of the library books and 16 schools did not have any library books. From the 14 schools that had some library books, 11 schools indicated that the library books were locked in boxes and cabinets. When asked why library books were locked in metal boxes, a headmaster said:

We do not have a library room to keep or display these books where pupils can go in and select the books they want to read. We do not allow pupils to borrow them because when they take them home, they damage them, some throw them away and some too do not return them (Key Informants interview, February, 2018).

A library prefect confirmed that the school had some copies of library books but bitterly complained: "Our teachers deny us access to the library books. They do not allow us to borrow the books with the reason that when we take them, we will spoil them or misplace them (Pupil, February, 2018)".

Lack of shelves and the fear that students would damage or misplace library books are not enough reasons why library books should be locked up in metal boxes. The locking of library books in the metal boxes implies that the knowledge, skills and potentials of future leaders and workforce are locked up in those boxes.

\section{School Management and Supervision of Teachers}

This section of the paper examines teacher availability and deployment, regularity and punctuality, classes in session and pupils' exercises.

Teacher availability and deployment in Nandom Municipality

Acute shortage of qualified trained teachers was another debilitating factor that undermined quality education delivery in basic schools in Nandom Municipality. Trained-teacher-pupil-ratio per the sampled schools visited stood at 1:190; 1:71 and 1:51 for the Kindergarten (KG), primary and JHSs respectively. This is in excess of the 1:25 professionally trained teacher to pupil ratio recommended by the Ghana Education Service (GES). It is instructive to note the high degree of absence of qualified teachers at KG level where foundational learning is to be established. Due to the severe shortage of teachers in Nandom, school management adopts a strategy of assigning qualified teachers to the JHS with the hope of maximising chances of improved academic performance at the BECE while depriving lower levels. While such a strategy is often adopted by school management in the peculiar 
situation of scarcity of qualified teachers, a national debate is called for in discussing prioritisation of teacher allocation. Teachers play a pivotal role in the teaching and learning processes by organising and imparting knowledge and skills to pupils. They supervise, build warm relation and set the tone of the classroom environment. Therefore, the shortage of professionally trained teachers particularly at the lower levels, affects learning and the overall academic performance of pupils in higher classes. However, in some urban schools it was found that there was teacher surplus since some teachers refuse postings to rural schools. The imbalances of teacher deployment affect quality education delivery. Adu-Agyem \& Osei-Poku (2012) rightly assert that quality education demands quality teachers more than any other resources.

Teacher Regularity and Punctuality in Nandom Municipality In order to understand the dynamics behind the poor quality learning achievement in the Nandom Municipality, the study probed the extent and depth of contact time received by pupils by investigating teacher regularity and punctuality, interactions while classes are in session, and pupils' exercises.

Table 3: Teacher regularity and punctuality to school

\begin{tabular}{|c|c|c|c|c|c|c|c|}
\hline Variable & \multirow[t]{3}{*}{ Description } & \multicolumn{4}{|c|}{ School location } & \multirow{2}{*}{\multicolumn{2}{|c|}{ Total }} \\
\hline \multirow{5}{*}{$\begin{array}{l}\text { Teacher } \\
\text { regularity }\end{array}$} & & \multicolumn{2}{|c|}{ Urban Area } & \multicolumn{2}{|c|}{ Rural Area } & & \\
\hline & & Count & $\%$ & Count & $\%$ & count & $\%$ \\
\hline & Present & 69 & 88.5 & 81 & 68.6 & 150 & 76.5 \\
\hline & Absent & 9 & 11.5 & 37 & 31.4 & 46 & 23.5 \\
\hline & Total & 78 & 100 & 118 & 100 & 196 & 100 \\
\hline \multirow{5}{*}{$\begin{array}{l}\text { Teacher } \\
\text { punctuality }\end{array}$} & Time reported & \multicolumn{2}{|c|}{ Urban Areas } & \multicolumn{2}{|c|}{ Rural Area } & \multicolumn{2}{|l|}{ Total } \\
\hline & to school & Count & $\%$ & Count & $\%$ & count & $\%$ \\
\hline & 6:00-8:00 am & 57 & 82.6 & 41 & 50.6 & 98 & 65.3 \\
\hline & 8:01 and above & 12 & 17.4 & 40 & 49.4 & 52 & 34.7 \\
\hline & Total & 69 & 100 & 81 & 100 & 150 & 100 \\
\hline
\end{tabular}

Source: Field survey, 2018

Another teacher management factor affecting quality education delivery is teacher lateness and absenteeism. From Table 3, out of 196 basic school teachers observed, $23.5 \%$ of teachers were not present at post at the time of visit. Teacher absenteeismin urban schools was comparatively lower (11.5\%) than rural schools, which stood at $31.4 \%$. The $11.5 \%$ implied that many teachers in urban schools attend school regularly than teachers who teach in rural areas. Over all, the study found 
that $23.5 \%$ of teachers in the Municipality were frequently absent from school. On teacher punctuality, the survey revealed that a total of $34.7 \%$ of teachers habitually go to school late. About $17.4 \%$ and $49.4 \%$ of teachers in urban and rural schools respectively reported to school after 8:30am, the official reporting time. This implies that teacher lateness was high in rural areas/schools than teacher lateness in urban schools.

Teachers' absenteeism and lateness reduce the contact hours and these acts consequently affect teachers' ability to complete the syllabus and diminish quality learning (Frempong, 2011). An interview conducted with an executive member of the Parent Teacher Association (PTA) on teacher punctuality and regularity revealed that some PTAs are unable to discipline teachers as revealed in this statement: "Some teachers come to school late and some absent themselves from school without any reason. But we are afraid to notify the authority for the fear that the office will transfer them and they will not be replaced" (Key Informants interview, February, 2018).

In an interview, a headmaster confirmed:

Teachers' absenteeism arises when teachers are bereaved, fall sick, attend sandwich and distance learning programmes, weekend travels, rainfall or given assignment to attend other official duties. However, their lateness to school was due to the long distance they commute to school each day. (Key Informants interview, February, 2018).

The study found that only $7.8 \%$ of the teachers reside within the rural communities in which they teach while $92.2 \%$ stayed outside their school communities. The 92.2\% of teachers who lived outside their school communities were living in town communities such as Nandom, Ko and Hamile and commute daily to school (situated in rural communities). The study revealed that even teachers who teach in their communities rented accommodations in towns. Probing further to ascertain why teachers who teach in their own communities had abandoned their own houses, where there is free accommodation but rather hired rooms in towns and commute six kilometres to school daily, the teachers lamented: "When you live in your own community your people are always worrying you and pestering you for money and other things. They do not even respect you when you live in your own community and work" (Key Informants interview, July 2018). 
This finding does not support Dunnes and Leach (2010) position that teachers who lack accommodation facilities in schools are compelled to stay far places in towns. We infer that teachers who hail from particular communities did not like to stay there due to issues of familiarity, which erodes respect. In addition, there is the factor of the social responsibility of care, expected from persons with salaried jobs. This is not to suggest that teachers do not care about their relatives, but that it can be burdensome to shoulder all the financial and other demands that are placed on salaried workers.

Poor supervision by school managers in the utilisation of instructional time was another management related factor found to be hindering quality education delivery in basic schools in Nandom. Out of 30 classes observed at the KG level, $36.9 \%$ of them were in session, whereas $63.3 \%$ of the classes were not in session. Similarly, at the primary school level out of the 90 classes observed, $52.2 \%$ of the classes were not in session. While at the Junior High school level out of 45 classes observed, $37.8 \%$ of the classes were not in session. Averagely, $49.7 \%$ of the classes were found to be in session while $50.3 \%$ of the classes, lessons were not in session. All classes we observed during the instructional period between 8:00 am and 1:00 $\mathrm{pm}$. It was observed that some teachers were either sitting under trees chatting, browsing their smart phones or using the instructional period to prepare their lesson notes in order to satisfy school heads and supervisor demands. It was found that none of the schools had teacher-class attendance registers to track teachers' attendance in taking their lessons. This in part has resulted in the high classabsenteeism of teachers.

\section{Number of Exercises and Assignments}

Teacher work-output was another teacher related factor inhibiting quality education. The study found that teacher work-output in terms of the number of assignments and exercise teachers gave children per term was inadequate. A review of the pupils' exercise books showed that out of the 90 pupils' English Language exercise books sampled randomly, $48.9 \%$ of the pupils had less than five exercises, $34.4 \%$ had exercises ranging between five and nine, and $16.7 \%$ had exercises above nine within two terms. As regards Mathematics, it was observed that out of the 90 pupils exercise books reviewed, $45.6 \%$ of pupils had exercises ranging from zero to four, $36.7 \%$ had exercises between five and nine while $17.7 \%$ had exercises above nine. It was also observed that $32 \%$ and $25 \%$ of the exercises given in English Language and Mathematics respectively over two months were not marked. Even those that were marked did not have corrections done. This implied that the pupils 
were deprived of feedback, which is necessary for corrections, knowledge and skills acquisition. This phenomenon suggests that supervision from their headteachers and circuit supervisors were inadequate or non-existent.

\section{Family Background Factors Affecting Quality Education Delivery}

The study found that family background factors such as parents' educational status and occupations affect quality education delivery. On parents' educational status, $60 \%$ of parents said they were illiterates, $26.7 \%$ had basic and secondary education and $13.3 \%$ had tertiary education. This suggested that $60 \%$ of pupils whose parents were illiterates could not get any assistance from their parents with regard to exercises, assignments and homework. A parent confirmed this when he said:

My inability to read and write is affecting my children in school because I cannot open their books or terminal report and know how they are performing or guide them to do their homework (Field work, PTA member March, 2018).

Parental support to children in school beyond the normal livelihood provisioning is crucially vital for children's learning achievements.

Table 4: Parents' income status and investment in education

\begin{tabular}{|l|l|l|l|l|l|l|l|}
\hline Variable & Level & $\begin{array}{l}\text { Monthly } \\
\text { Income } \\
\text { (GhS) }\end{array}$ & Freq. (f) & $\%$ & $\begin{array}{l}\text { Cumulative } \\
\text { Frequency }\end{array}$ & $\begin{array}{l}\text { Mid-point } \\
(\mathrm{x})\end{array}$ & FX \\
\hline \multirow{2}{*}{$\begin{array}{l}\text { Parents' } \\
\text { income } \\
\text { status }\end{array}$} & Low & $1-120$ & 10 & 66.7 & 10 & 60.5 & 605 \\
\cline { 2 - 9 } & Middle & $121-240$ & 3 & 20 & 13 & 180.5 & 541.5 \\
\cline { 2 - 9 } & High & $241+$ & 2 & 13.3 & 15 & 300.5 & 601 \\
\cline { 2 - 8 } & TOTAL & 15 & 100 & & & 1747.5 \\
\hline
\end{tabular}

Field survey, 2018

The study unearthed that low financial status of parents hinders quality education as parents are unable to invest in their children education which human capital theory (HCT) advocated for. From Table 4, many parents $(66.7 \%)$ indicated that in a month they received income between one and one hundred and twenty cedis (Ghc 1-120) This is within the low-income bracket and extreme poverty. They explained that they often find it extremely difficult to meet their financial obligations towards their wards education because there are other competing and equally important responsibilities. They further explained that even though they do not pay school 
fees, they are still compelled to pay PTA levies, examinations fees, purchase school uniform and footwear and stationeries. These far outweigh the income they receive.

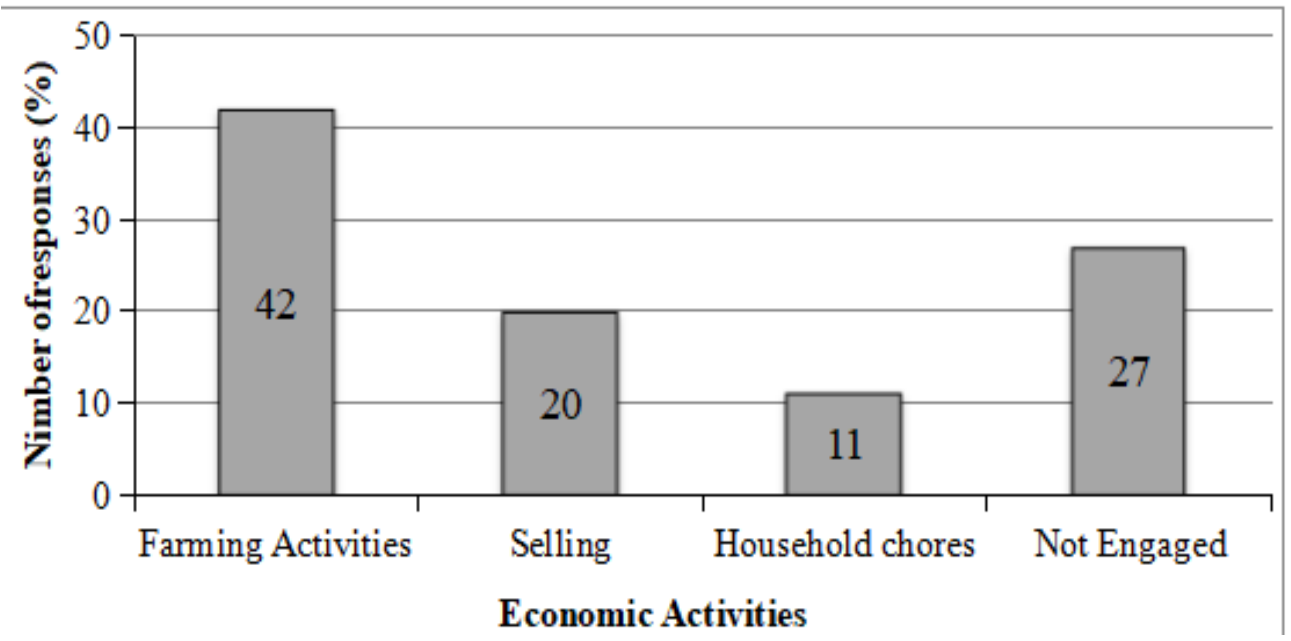

Figure 1: Type of economic activities parents engaged students Source: Field survey, 2018

As a result of poor household incomes, families require children to help in income generating activities such as on the farm and sale of farm produce in the market. Engagement of pupils in farming and income generation activities affect quality learning as pupils intermittently absent themselves from school during the farming season. From Figure $1,42 \%$ of pupils said they were engaged in farming activities, $20 \%$ in selling of pito, cakes, charcoal, firewood and table-top business, $11 \%$ in household chores such as washing, cooking, sweeping and baby care while $27 \%$ also said they were not engaged. Respondents indicated their parents sometimes ask them to stop school and assist them either in farming or trading. A parent in an interview confirmed: "In the rainy season I ask my children to stop school and help me in the farm when the work is too much" (Field work, PTA member, February, 2018).

Another key challenge confronting quality education delivery and schooling in Nandom are related to social gatherings such as market days and funerals. Forty percent of the respondents indicated that pupils' attendance on market days was high, $12.2 \%$ of the respondents were uncertain and $47.8 \%$ said pupils' attendance to school on market days was low. This implied that many pupils absent themselves from school on market days. Some of the markets identified are Baselbe market, Hamile market and the Burkina market. On these market days, which take place 
every fifth day, pupils absent themselves from school, others run away from classes and in most cases schools are closed early. It was revealed that some pupils abandon classes on market days and go to the market to pick merchandise and go round and sell them on commission basis. The absence of pupils from school due to markets days and funerals negatively affects quality education delivery as pupils missed some lessons.

\section{Stakeholder Perspectives on Strategies for Improving Basic Education in Nandom}

Improving school management efficiency and effectiveness was found to be a key strategy of providing quality education for students. From table 5, 97.4\% and 80\% of teacher and supervisor respondents respectively indicated that improvement on management effectiveness was a strong strategy for improving quality education delivery in basic schools.

Table 5: Strategies for improving quality education in basic schools

\begin{tabular}{|l|l|l|l|l|}
\hline \multirow{2}{*}{ Strategies } & \multicolumn{2}{|l|}{$\begin{array}{l}\text { Teacher respondents } \\
(\mathrm{n}=115)\end{array}$} & \multicolumn{2}{l|}{$\begin{array}{l}\text { Supervisor } \\
\text { respondents } \\
(\mathrm{n}=5)\end{array}$} \\
\cline { 2 - 6 } & Strong & Weak & Strong & Weak \\
\hline $\begin{array}{l}\text { Improve school management } \\
\text { effectiveness and accountability. }\end{array}$ & $\begin{array}{l}112 \\
(97.4 \%)\end{array}$ & $\begin{array}{l}3 \\
(2.6 \%)\end{array}$ & $\begin{array}{l}4 \\
(80 \%)\end{array}$ & $\begin{array}{l}1 \\
(20 \%)\end{array}$ \\
\hline $\begin{array}{l}\text { Improve working conditions of } \\
\text { teachers in schools (school facilities and } \\
\text { professional development). }\end{array}$ & $\begin{array}{l}95 \\
(82.6 \%)\end{array}$ & $\begin{array}{l}20 \\
(17.4 \%)\end{array}$ & $\begin{array}{l}5 \\
(100 \%)\end{array}$ & $\begin{array}{l}0 \\
(0 \%)\end{array}$ \\
\hline $\begin{array}{l}\text { Enhance social amenities in deprived } \\
\text { areas (water, electricity, roads, mobile } \\
\text { phone network etc) }\end{array}$ & $\begin{array}{l}105 \\
(91.3 \%)\end{array}$ & $\begin{array}{l}10 \\
(8.7 \%)\end{array}$ & $\begin{array}{l}4 \\
(80 \%)\end{array}$ & $\begin{array}{l}1 \\
(20 \%)\end{array}$ \\
\hline $\begin{array}{l}\text { Enhance community participation and } \\
\text { accountability }\end{array}$ & $\begin{array}{l}101 \\
(87.8 \%)\end{array}$ & $\begin{array}{l}14 \\
(12.2 \%)\end{array}$ & 5 & $\begin{array}{l}10 \\
(0 \%)\end{array}$ \\
\hline $\begin{array}{l}\text { Focus on teacher recruitment and } \\
\text { posting based on their community of } \\
\text { origin. }\end{array}$ & $\begin{array}{l}24 \\
(20.9 \%)\end{array}$ & $\begin{array}{l}91 \\
(79.1 \%)\end{array}$ & $\begin{array}{l}1 \\
(20 \%)\end{array}$ & $\begin{array}{l}4 \\
(80 \%)\end{array}$ \\
\hline Source Field survey, 2018 & & & & \\
\hline
\end{tabular}

Headmasters and circuit supervisors believed that improvement in school management effectiveness and efficiency and accountability has the highest 
possibility of improving quality teaching and learning in schools. Respondents were of the view that effective school management and accountability would ensure that school resources are well managed and directed towards improving quality teaching and learning.

Improvement of teacher working conditions such as improved conditions of service, professional development, infrastructure and teaching and learning materials in schools was found to be a key strategy for improving quality teaching and learning in basic schools. About eighty-threeand hundred percent of teacher and circuit supervisor respondents respectively showed that enhancement of teacher working conditions was a good strategy for quality education. Respondents emphasised that enhancement of teacher working conditions such as the improved conditions of service that teacher unions are agitating for, upgrade in school infrastructure and provisioning of educational materials and professional development programmes for teachers would restore teachers' status, value, recognition and the dignity. On the conditions of service, respondents believed that hardworking and committed teachers who accept postings to remote areas should be given automatic promotion to the next rank. Respondents said continuous professional development programmes such as seminars and in-service training should be organised regularly for teachers to update their professional skills.

Improvement of social amenities in rural areas is another crucial strategy for improving quality education for all. About ninety-one percent and $80 \%$ of teacher and supervisor respondents respectively believed that the provision of social amenities in rural and other hard-to-reach communities is a strong strategy for improving quality education. A teacher respondent interviewed complained: "Getting means to travel to market to buy ingredients, potable water, health facility, electricity to charge our phones and even mobile network service is difficult for us in this community" (Teacher informant interview, February, 2018). Teachers do not want to accept postings to rural communities or live in villages because of the non-availability of basic social amenities. Improvement in basic social amenities such as healthcare, potable water, electricity, good roads, transportation, market, recreational centres and mobile network services, internet service in villages and rural areas were found to be major strategies for attracting and retaining more qualified teachers in rural schools to provide quality education for all (Frempong, 2011; Zvavahera, 2010).

Enhancing community participation in school management was another key strategy for improving quality education in basic schools. From Table 5, 87.8\% 
and $100 \%$ of teacher and supervisor respondents respectively indicated that enhancement of community participation in school management was a strong strategy for improving quality teaching and learning in schools. The respondents indicated that active community participation in school management would improve quality education by raising funds for school development, ensure regularity and punctuality of pupils, provide and repair school facilities, provide land, labor and volunteer teaching, intensify school monitoring and ensure teacher accountability, provide security for teachers, foster unity among school and community members. The study revealed that active participation of community leaders such as chiefs, assembly members, priests and other opinion leaders would boost teachers and pupils' morale to work to improve learning and academic performance outcomes.

Surprisingly, it was found that as high as $79.1 \%$ and $80 \%$ of teacher and supervisor respondents, indicated that recruitment and postings of teachers to their own communities to teach was a weak strategy for improving quality education. Respondents believed that this strategy can deny some pupils qualified teachers and subsequently affect their learning and performance in school. Recruiting teachers, who hail from within the communities has been advocated by policy makers and activists in the education sector. Respondents explained that recruiting teachers from communities to teach in their own communities has the highest possibility of denying many communities from getting teachers since not all communities have literates who can be recruited as teachers. This finding, however, contradicted UNESCO's (2015) position that local recruitment of teachers would retain teachers in rural areas and deprived communities and a panacea for improving quality education.

\section{CONCLUSION}

Education plays a critical role in the development of individuals and in their contribution to the progress of societies. Inadequate school resources, ineffective school management and supervision, low community participation and accountability, and parents' engagement of pupils in farming activities are major factors affecting quality education in Basic schools in Nandom Municipality. This study, inferring and drawing on the Ludwig Von Bertalanffy system theory analytical framework and human capital theory, postulates that the poor education outcomes in Nandom are explained by the multiplicity and multi-faceted inputs and poor processes that have bedeviled Nandom Municipality. Adequate investment of 
resources and efficient interactive teaching-learning processes are crucial factors in the provision of quality education. Quality education demands adequate resources, effective school management and good working conditions of teachers.

One of the crucial but less explored sources of support for schools come from communities. Pupils' learning achievements would remain low until communities begin to fully participate, collaborate and see themselves as partners in education by contributing in kind and cash to enhance the quality of education.

The study recommends that government and non-governmental organisations provide adequate resources to improve the teaching condition in schools. There is the need for GES to deploy teachers equitably and intensified monitoring and supervision. The decentralisation concept of school management and accountability whereby communities participate and demand accountability in schools should be well implemented by the Ghana Education Service in partnership with local and international stakeholders in education. The Municipal Assembly in conjunction with the education directorate and community leaders should enact bye-laws to prohibit parents from engaging pupils in farming and income generating activities during school instructional hours.

\section{REFERENCES}

Abdallah, H., Fuseini, M. N., Abudu A. M., \& Nuhu, Y. (2014). Dilemma of basic school pupils in Northern Ghana with respect to their learning context. Education Research International, 12(2), 1-13.

Adedeji, S. O. \& Olaniyan, O. (2011). Improving the conditions of teachers and teaching in rural schools across African Countries: Fundamentals of teacher education development. UNESCO-IICBA, Addis Ababa, 1-28.

Adu-Agyem, J., \& Osei-Poku, P. (2012). Quality Education in Ghana: The Way Forward. International Journal of Innovative Research and Development, 5(2), 243- 358.

Amaah, E. O., Ato-Davies, A., Kpeyibor, P. F., Semordey, C. R., \& Oppong, J. D. (2019). Poor Academic Performance of Students in Ghana: Appraisal of Wamfie Circuit Junior High Schools in Dormaa East District. Education Journal, 2(1), 67-76. Availableon www.itspoa.com/journal/edu.

Ampofo, E. T., \& Osei-Owusu, B. (2015). Students' Academic Performance as Mediated by Students' Academic Ambition and Effort in the Public Senior High Schools 
in Ashanti Mampong Municipality of Ghana. International Journal of Academic Research and Reflection,3(5), 19-23. Progressive Academic Publishing, UKAvailable on: www.idpublications.Org

Babalola, H. (2003). Economic Growth and Human Development. Nsukka: University Press.

Becker, G. (1994). Human Capital: A Theoretical and Empirical Analysis with special reference to Education (3rd ed.). Chicago University of Chicago Press.

Bohlander, G., Snell, S.A., \& Sherman, A. (2001). Managing Human Resource $\left(12^{\text {th ed.). }}\right.$

South-Western College Publishing, Cincinnati, $\mathrm{OH}$.

Bourdieu, P., \& Passeron, J. C. (1990). Reproduction in Education, Society and Culture. Translated by Richard Nice (3rd ed.). London: Sage Publications.

Casely-Hayford, L., Seidu, A., Campbell, S., Quansah, T., Gyabaa, T., \& Rukayatu, A. (2013). The Quality and Inclusivity of Basic Education across Ghana's three Northern Regions: A look at change, learning effectiveness and efficiency. TENI Project VSO and AFC, Ghana, 1-243.

Dunne, M., \& Leach, F. (2010). Gendered school experiences: the impact on retention and achievement in Botswana and Ghana. London: DFID.

Frempong, E. (2011). Factors contributing to poor performance of students in Basic Education Certificate Examination in selected Public JHS in Effutu Municipality, Ghana (Unpublished master's Thesis) UEW, Ghana.

GES BECE Performance Analysis (2017). National, regional and district performance analysis. GES, Upper West Region, Ghana.

Ghana - Sustainable Development Goals (SDGs) (2017). Why they matter an how we can help. UN Communication Group in Ghana and CSO Platform on SDGs Ghana MDG: 2015 Report, UNDP-Ghana.

GSS (2014). District Analytical Report of Nandom District. Ministry of Foreign Affairs of Denmark; International Development Cooperation, DANIDA, Canada.

Haque, S., \& Rehman, N. (2014). Modern organisation theory: Analyzing the complexity of coordination and cooperation in the modern organisations. Jamshoro; PAK International Journal of Management and Sustainability, 3(5), 261-268.

Haseena, V. A., \& Mohammed, A. P. (2015). Aspects of quality in education for the improvement of educational scenario. Journal of EducationanPractice, 6(4), 100-105. Available at: $w$ ww.iiste.org. 
Madani, R. A. (2019). Analysis of educational quality, a goal of education for all policy. Higher Education Studies, 9(1), 100-109. Canadian Center of Science and Education.

Mathieu, J., Maynard, M., T., Rapp, T., \& Gilson, L. (2009). Team effectiveness 19972007: Review of recent Advancements and Glimpse into the Future. Journal of Management, 34 (1), 410-476.

Moreland, R. L. (1996). Lewin's legacy for small-groups sesearch; quantitative and qualitative approaches. Nariobi: African Centre for Technology.

Olaniyan, D. A., \& Okemakinde (2008). Human capital theory: Implications for educational development, Pakistan. Journal of social sciences, 5(1), 479-483.

Ramatu, A. (2014). The effects of school infrastructure on pupils' academic performance in Tamale Metropolis, (Unpublished Master thesis). University for Development Studies, Tamale.

Samuel, B. (2012). Factors influencing leadership and teacher performance in Senior High Schools in the Ho Municipality of the Volta Region of Ghana (Unpublished master's Thesis). KNUST, Ghana.

Schindler, L., Puls-Elvidge, S., Welzant, H., \& Crawford, L. (2015). Definition of quality in higher education: A synthesis of the literature. Higher Learning Research Communications, 5(3), 3-13. tt://dx.doi.org/10.18870/hlrc.v5i3.244

Schultz, T. W. (1971). Investment in human capital. New York: The Free Press.

Suriyankietkaew, S., \& Hallinger, P. (2019). Empirical research on education for sustainable development in Sufficiency-Based Schools. South Africa. European Journal of Sustainable Development, 7(3), 205-216.

Thangeda, A., Baratiseng, B., \& Mompati, T. (2016). Education for sustainability: qualityeducation is anecessity in the modern day. How far do educational institutionsfacilitate quality education? Journal of Education andPractice.Vol. 7 (2) p. 9-17. Available online: www.iiste.org. Accessedon 5th November, 2020.

UNESCO (2015). EFA Global monitoring report (2015). Education for all 2000-2015: Achievements and challenges. UNESCO Publishing, Paris France.

UNESCO (2014). Aichi Nagoya Declaration on education for sustainable development. Retrieved on 4th November, 2020 from http://unesdoc.unesco.org/ images/0023/002310/231074e.pdf 
UNESCO (2012). ASIA - PACIFIC: End of decade Notes on education for ALL: Quality in education. Published by UNESCO Bangkok, UNICEF EAPRO and UNICEF ROSA.

UNICEF (2015). Annual report on education; UNCEF Publication.

UNICEF-Ghana (2013). Advocating for development that Leaves no child behind. Accra - North, Ghana, West Africa.

Zainul-Deen, B.D. (20II). An Assessment of Ghana's policy on quality education in the public senior high schools: A Case study of the Ahafo and North and South Districts.(Unpublished Master's Thesis), KNUST, Ghana.

Zvavahera, P. (20I0). Human capital problem in Zimbabwean rural schools: A case study of Mazowe District. Ministry of Environment and Natural Resources Management. Journal for Computing Science and Engineering, I(I), 2I - 34. 